\title{
The efficiency of bees in pollinating ephemeral flowers of Jacquemontia bracteosa (Convolvulaceae)
}

\author{
Sîlvia K. D. Santos \& Miriam Gimenes
}

Universidade Estadual de Feira de Santana (UEFS), Campus Universitário, Rodovia BR-116, Km 3, 44031-460, Feira de Santana, Bahia, Brazil. (mgimenes@uefs.br)

Received 16 November 2015.

Accepted 15 September 2016.

DOI: $10.1590 / 1678-4766 e 2016025$

\begin{abstract}
The family Convolvulaceae is widely distributed in tropical regions, mainly in open areas. Convolvulaceae flowers are characterized mainly by being beautiful and ephemeral, attracting many flower visitors that belong to different taxonomic groups. This work aimed to investigate the interactions between insects and flowers of Jacquemontia bracteosa (Convolvulaceae), focusing on the pollination efficiency, in an area in the Brazilian semiarid. From November 2011 to October 2012, floral biology of J. bracteosa was investigated as well as the flower visit frequency, behavior, and morphology of floral visitors. The flowers of $J$. bracteosa are white, showy and open early in the morning, lasting less than 12 hours, with fruiting occurring both by selfing and outcrossing fecundation. A total of 337 specimens insects were collected on J. bracteosa flowers during the field observations. The Neotropical bee, Ancyloscelis apiformis, was considered the most efficient pollinator of J. bracteosa. This bee showed appropriate behavior, high frequency ( $64 \%$ of the total sample), and was constant on the flowers. Furthermore, they arrived soon when the flowers began to open and presented $90 \%$ of efficiency in tests of flower pollination of $J$. bracteosa. Other native bee species also visited the flowers of $J$. bracteosa and may be considered potential pollinators because they presented behavior and morphology compatible with the flowers. This study suggests that maintenance of weeds or ruderal plants, especially those that also have ornamental potential in anthropic area, may be an option for the preservation of local native pollinators, which are threatened by environmental degradation.
\end{abstract}

KEYWORDS. Pollination, Ancyloscelis apiformis, Augochlora, Jacquemontia bracteosa, Apoidea.

Members of the Convolvulaceae family, with worldwide distribution (JUDD et al., 2009), occur in the most diverse Brazilian vegetation formations, from the Caatinga to the Amazon, usually associated with open field environments and forest edges (Simão-Bianchini \& PIRANI, 2005). Species of this family are predominantly heliophytic vines that grow rapidly in areas with early succession vegetation and deciduous forests, where neighboring plant species, of small stature, provide adequate support (MCDonALD, 1991).

Some members of the Convolvulaceae family, as genus Merremia Dennst. ex Endl, and Ipomoea L., are considered weeds or ruderal because present rapid growth, occurring frequently in crops areas (TIMOSSI \& DuRIGAN, 2006) and anthropogenic environments such as wastelands and roadsides (Ferreira \& Miotto, 2009). The genus Jacquemontia Choisy, with origin and distribution in tropical America (Simão-Bianchini, 1999), is also common in open fields and anthropized areas, providing thus the food resources to visitors, especially native bee pollinators (MAIA-SILVA et al., 2012).

Among the studies focusing on flower visitors and pollination system of Convolvulaceae, some genus are well known as Ipomoea, being bees the main pollinators of flowers (KiIll \& Ranga, 2003; Maimoni-Rodella \& Yanagizawa, 2007; MCMullen, 2009; PaCheCo Filho et al., 2011), but in other genus as Jacquemontia, knowledge is fairly crude. Some studies on pollination of Jacquemontia spp. put the bees as the main pollinators of flowers (SILVA et al., 2010; KIIL \& Simão-Bianchini, 2011). The flowers of Jacquemontia multiflora were visited by butterflies and especially by bees, including the introduced $A$. mellifera Linnaeus, 1758, in northeastern Brazil (PIEDADE-KIILL \& RANGA, 2000).

This study proposes to investigate the floral biology and pollination of $J$. bracteosa with emphasis on morphological adaptations and foraging behavior of floral visitors in an area in the Brazilian semiarid. Having regard to importance of the pioneer species, also known as ruderal as Jacquemontia spp. in anthropogenic environments. This is important for the maintenance of native floral visitors and the also scarcity of studies on this topic.

\section{MATERIALS AND METHODS}

The study was carried out on the campus of Universidade Estadual de Feira de Santana (UEFS) (12 $11^{\prime}$ '56.3'S and 38 58'07.6”W, ca. $243 \mathrm{~m}$ a.s.1.) in Feira de Santana, Bahia, northeastern Brazil. The UEFS Campus comprises an area of approximately $1.2 \mathrm{~km}^{2}$; the vegetation is predominantly herbaceous-shrub Caatinga, with currently introduced and invasive plants (SANTANA \& SANTOS, 1999). 
The regional climate is semiarid (Köppen's classification), with average temperatures varying between 20.7 and $26.8^{\circ} \mathrm{C}$ and annual rainfall varying from 500 to 800 $\mathrm{mm}$ (SEI, 2011). The macrometeorological data relating to temperature, rainfall and relative humidity were obtained from the Climatological Station of UEFS during the months from November 2011 to October 2012. November 2011 was the wettest month while January and March 2012 were the driest. The highest humidity value $(88 \%)$ was registered in May and the lowest (67\%) in October. The lowest average temperature during the day $\left(\mathrm{ca} .24^{\circ} \mathrm{C}\right.$ ) was observed in June and the highest average temperature $\left(\mathrm{ca} .30^{\circ} \mathrm{C}\right.$ ) was observed from October to January (Fig. 1).

In the study local, the species occurs spontaneously in the vegetation. Data were collected monthly from November 2011 to October 2012, during three days by each month. Due to the difficulty in individualizing the plants, this study covered four areas of approximately $10 \mathrm{x} 10 \mathrm{~m}$ each. Flowering phenological data were obtained by counting the number of flowers opened at one of the observation areas during each month of study.

For morphometry we used 10 flowers fixed in alcohol $70 \%$. We measured the diameter and length of corolla and calyx, and the height of stamens and filaments. Flower size (classification of MACHADO \& LOPES, 2004) and flower types (classification of VIDAL \& VIDAL, 2000) were considered. Data on flower color, number of stamens, anthers and stigma characteristics, location and type of floral resource produced, and flower opening time and closing time were also recorded. The stigmatic receptivity was determined from the immersion of the stigmas of different flowers $(\mathrm{n}=10)$ in a Petri dish containing $10 \%$ hydrogen peroxide $\left(\mathrm{H}_{2} \mathrm{O}_{2}\right)$, monthly on preanthesis buds (shortly before the full opening of flowers), at each hour interval, throughout the flower's duration. The formation of bubbles on the surface of the stigma indicated its receptivity (DAFNI \& MAUÉs, 1998).

Floral aromas and the presence of osmophores were evaluated (DAFNI et al., 2005). The presence of pigments that reflect ultraviolet light was observed from the exposure of five flowers to ammonia hydroxide vapor (PA). These flowers were placed in a container with cotton and ammonia hydroxide for 20 seconds. The formation of dark spots indicated the presence of these pigments (SCOGIN et al., 1977).

The reproductive biology of the species was determined using at least 15 flowers marked of different plants (in previously-bagged flower in pre-anthesis) by each treatment: spontaneous self pollination, manual self pollination (autogamy), cross pollination (geitonogamy and xenogamy) and apomixis (with previously emasculated flower). After treatments, bagged flowers were followed until fruit development. In the natural control, 15 flower buds in pre-anthesis were only marked and the flowers were followed for their whole duration. All treatments were performed in July.

Flower visitors were collected and observed monthly, from November 2011 to October 2012, during two days, at intervals of 30 minutes of each hour, from flower opening to closing. Individuals which collected some kind of floral resource (pollen and/or nectar) in these flowers were considered flower visitors.

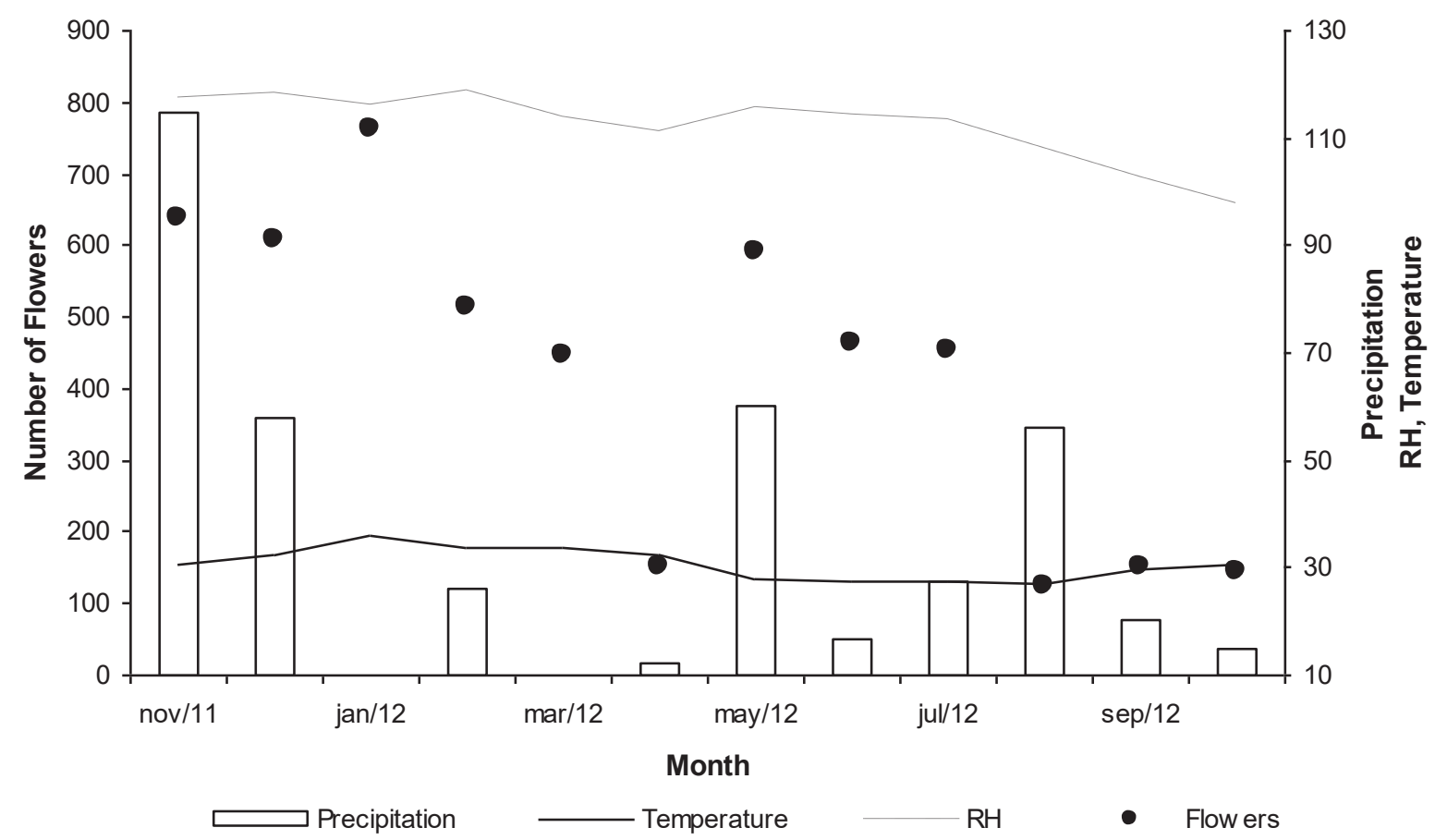

Fig. 1. Total number of flowers open in Jacquemontia bracteosa Meisn. (Convolvulaceae), daily and monthly, and rainfall (mm), relative humidity (\%), and temperature $\left({ }^{\circ} \mathrm{C}\right)$ in the campus of Universidade Estadual de Feira de Santana, BA, Brazil between November 2011 and October 2012. Source: Weather Station of UEFS. 
Visitor constancy was calculated using the formula: Constancy $=($ Number of samples with species/Number of samples) $\mathrm{x}$ 100. According to the values obtained, species were classified into: $\mathrm{C}=$ common (or constant, $\mathrm{C}>50 \%$ ), $\mathrm{A}=$ accessory $(\mathrm{C}=>25 \%<50 \%)$, and $\mathrm{Ac}=$ accidental $(\mathrm{C}$ $<25 \%$ ) (Thomazini \& Thomazini, 2002).

To analyze the morphological characteristics of each flower visitor species, 10 individuals were collected to measure their body length (between the median ocellus and the end of the abdomen) and intertegular width (the distance between wing bases) (classification followed FRANKIE et al., 1983). The measures were carried out in the most frequent species and considered common. The foraging behavior of flower visitors was analyzed by direct visual observations and with the help of photographs.

The experiments to verify the efficiency of flower visitors most frequent on flowers were carried out using 10 flower buds, previously-bagged at the night before the experiment. On next day, the flowers were exposed for a short time to allow three visits from floral visitors (of the same species). After that, the flowers were bagged and observed until fruit development.

The flower visitors collected were deposited in the Entomological Collection Prof ${ }^{\circ}$. Johann Becker of Museu de Zoologia da Universidade Estadual de Feira de Santana (MZFS), and vouchers of J. bracteosa were deposited in the Herbaria of UEFS.

\section{RESULTS}

Jacquemontia bracteosa. Jacquemontia bracteosa is a vine that uses shrubs and fences as a support or in absence of a structure to be used as a support the plant presents itself a creeping habit forming large tangles. These plants have funnel flowers, gathered on simple cymes on average with 12 buds per inflorescence ( $\mathrm{n}=15$ inflorescences) in different development stages, and from one to four flowers open daily per inflorescence. The flowers were classified as very large with $33.66 \pm 1.92 \mathrm{~mm}(\mathrm{M} \pm \mathrm{SD})$ corolla diameter, $10.97 \pm$ $0.79 \mathrm{~mm}$ aperture diameter of floral tube, and $17.1 \pm 1.70$ mm length.

The gynoecium is formed by a white stigma with varying heights, with $16.21 \pm 1.98 \mathrm{~mm}$ length. The androecium consists of five stamens with different heights, the longer ones reaching $13.21 \pm 3.2 \mathrm{~mm}$ length, while the shorter ones reaching $10.31 \pm 2 \mathrm{~mm}$. Flower offer pollen and nectar to their floral visitors.

The flowers were completely opened generally between 7:00 and 8:00 h, the flower closing occurred between 15:00 to 17:00 h, with flower duration of less than 12 hours.

The largest number of flowers was observed in January (763), with an average temperature of $36^{\circ} \mathrm{C}$, and the lowest number of flowers was observed in August (123) with an average temperature of $27^{\circ} \mathrm{C}$. During the flowering period, the rainfall varied a lot, with the rainfall peak recorded in November 2011 and driest period recorded between January and March 2012 (Fig. 1). The flowers had no noticeable odor, neither osmophores, nor pigments that reflecting ultraviolet light and the stigma presented receptive during the period that the flower had been open.

Results of experiments on reproductive biology are presented in Table I and have indicated that J. bracteosa was self-compatible, since the tests of spontaneous, induced selfpollination and geitonogamy resulted in fruit production, with the highest fruit set rates recorded in xenogamy experiments and control treatment.

Tab. I. Results of the experiments on reproductive biology carried out in flowers of Jacquemontia bracteosa Meisn. (Convolvulaceae) on the campus of Universidade Estadual de Feira de Santana, BA, Brazil.

\begin{tabular}{lccc}
\hline Experiments & $\begin{array}{c}\text { Flowers } \\
(\mathrm{n})\end{array}$ & $\begin{array}{c}\text { Fruits } \\
(\mathrm{n})\end{array}$ & $\begin{array}{c}\text { Success } \\
(\%)\end{array}$ \\
\hline Spontaneous self-pollination & 15 & 3 & 20 \\
Induced self-pollination & 15 & 5 & 33.3 \\
Hand cross-pollination (Geitonogamy) & 15 & 12 & 80 \\
Hand cross-pollination (Xenogamy) & 15 & 14 & 93.3 \\
Apomixis & 15 & 0 & - \\
Natural conditions /Control & 15 & 13 & 86.6 \\
\hline
\end{tabular}

Flower visitors. A total of 337 individuals insects were collected on $J$. bracteosa flowers during the field observations. Among these, most of the bees were mainly female of Ancyloscelis apiformis (Fabricius, 1793), the most frequent visitor species ( $54.6 \%$ of collected individuals) and common (or constant) on flowers, occurring in each month of flowering of the $J$. bracteosa. The largest number of this species individuals occurred in January and February 2012 (Fig. 2). Other species of bees were also considered common, but less frequent as Augochlora spp. (25.9\%), Ceratina aff. maculifrons Smith, 1854 (5\% collected), and Trigona spinipes (Fabricius, 1793) (3\%) (Tab. II). Some flower visitors had only one individual collected on flower during the entire study and were considered sporadic as the bees Exomalopsis analis Spinola, 1853 and Exomalopsis sp., and one Diptera (Syrphidae) and one butterfly (Lepidoptera, Hesperidae).

All bees that showed small size as females of $A$. apiformis, C. maculifrons, T. spinipes, and Augochlora spp. (Tab.le II) collected pollen and nectar in the flowers of $J$. bracteosa in a very similar way. These bees went inside of the flower, carrying out back forward movements inside the corolla and circular movements on the anthers and stigma. Bees foraged by moving forward and backward inside the flower corolla. During this behavior inside the flower, the pollen grains were passively trapped on the ventral and dorsal body parts of bees. These bees collected pollen by scraping anthers with the front legs and also with the mouthparts. The bees collected nectar walking through the wall of floral tube or through the central part where the anthers were, and inserting the glossa into the nectary located at the base of floral tube. During this proceeding the pollen grains were deposited on the head and ventral and dorsal body parts. After collecting pollen and nectar, bees gyrated $180^{\circ}$ heading to the edge of the corolla where initiated a process of body cleaning. 


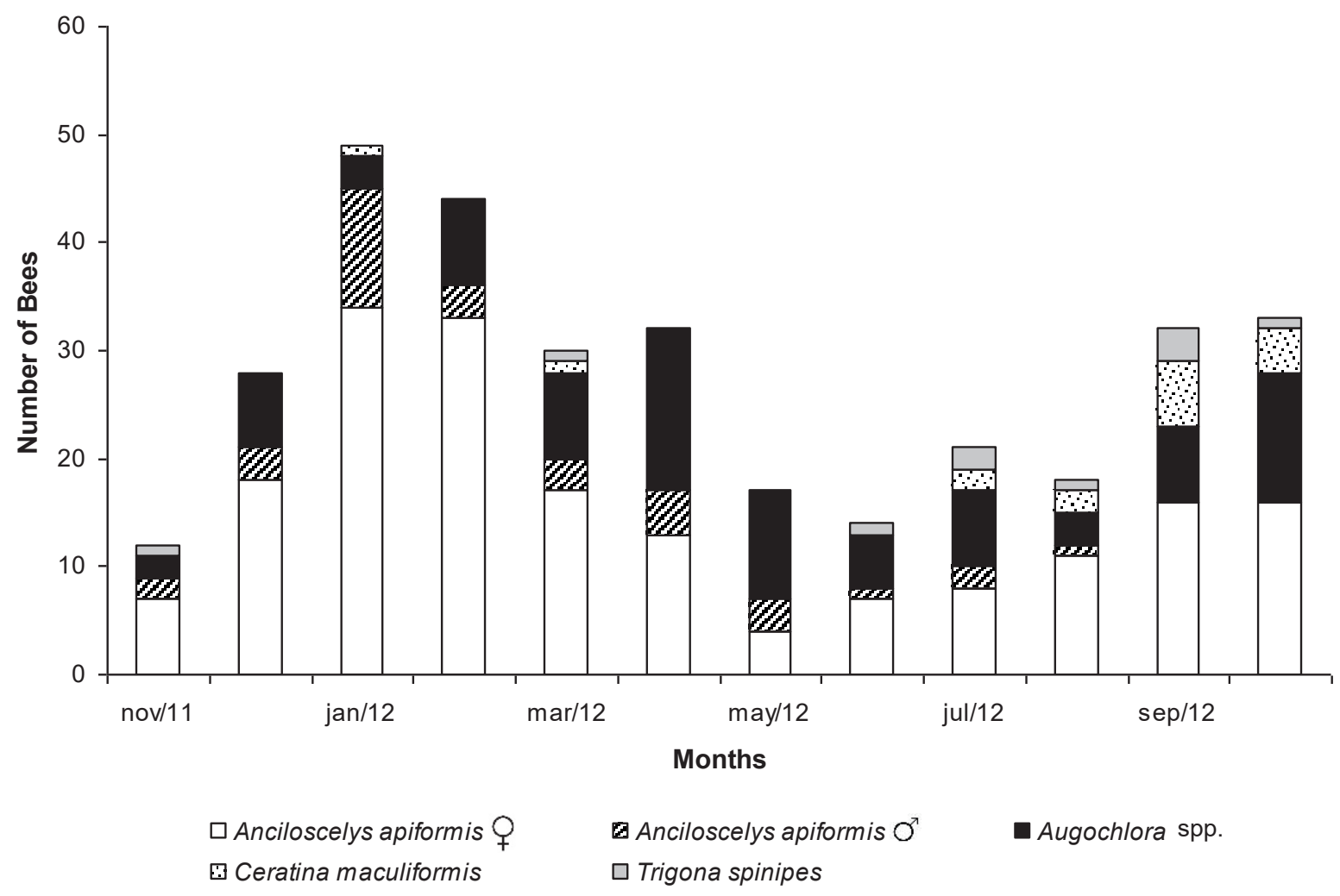

Fig. 2. Number of individuals of the main flower visitors of Jacquemontia bracteosa Meisn. (Convolvulaceae) collected throughout the day, in the campus of Universidade Estadual de Feira de Santana, BA, Brazil between November 2011 and October 2012 (Total number $\geq 10$ ).

Tab. II. Relative frequency (RF), resource collected (RC), Constancy classes (Co) and body size of flower visitors (Length - Width $=$ L - W) in Jacquemontia bracteosa Meisn. (Convolvulaceae) in the campus of Universidade Estadual de Feira de Santana, BA, Brazil between November 2011 and October 2012 [Resource Collected (RC): N, Nectar; P, Pollen. Constancy (Co): C, common; A, accessory; Ac, accidental].

\begin{tabular}{|c|c|c|c|c|}
\hline Species & RF (\%) & Co & $\mathrm{L}-\mathrm{W}(\mathrm{mm})$ & $\mathrm{RC}$ \\
\hline \multicolumn{5}{|l|}{ APIDAE } \\
\hline Exomalopsis analis Spinola, 1853 & 0.3 & Ac & & $\mathrm{P} / \mathrm{N}$ \\
\hline Exomalopsis sp. & 0.3 & Ac & & $\mathrm{P} / \mathrm{N}$ \\
\hline Ancyloscelis apiformis (Fabricius, 1793) female & 54.6 & $\mathrm{C}$ & $6.8-2.0$ & $\mathrm{P} / \mathrm{N}$ \\
\hline Ancyloscelis apiformis (Fabricius, 1793) male & 9.8 & $\mathrm{C}$ & $6.2-1.9$ & $\mathrm{~N}$ \\
\hline Trigona spinipes (Fabricius, 1793) & 3.0 & $\mathrm{C}$ & $5.9-2.4$ & $\mathrm{P} / \mathrm{N}$ \\
\hline Ceratina aff. maculifrons Smith, 1854 & 4.7 & $\mathrm{C}$ & $6.5-2.0$ & $\mathrm{P} / \mathrm{N}$ \\
\hline \multicolumn{5}{|l|}{ HALICTIDAE } \\
\hline Augochlora spp. & 25.9 & $\mathrm{C}$ & $6.4-1.7$ & $\mathrm{P} / \mathrm{N}$ \\
\hline Pseudaugochlora sp. & 0.9 & Ac & & $\mathrm{P} / \mathrm{N}$ \\
\hline
\end{tabular}

Among the common bees species on J. bracteosa, and which came in contact with the reproductive structures of flower, A. apiformis, was the most frequent and the pollination efficiency test showed that $90 \%$ of the experiments resulted in the fruit set after three visits of this bee to the flower.

Male of A. apiformis have collected nectar differently from females. Males entered into the flower, walking down the tube wall to the nectary, and during this behavior were not observed the deposition of pollen on the body of these males. When these males came out of the flower, they walked through the tube wall toward the edge of the corolla and then flew.
It was noted that $A$. apiformis males flew quickly among the flowers, apparently patrolling them, because they kept away other visitors, even the same species, that arriving near the flowers. They usually landed on a flower where stayed for some time. This was an observed behavior mostly after 12:00 $\mathrm{h}$ and remained until the flowers closing.

\section{DISCUSSION}

Characteristics of $J$. bracteosa, as the presence of many and showy flowers, make the plant stand out from the vegetation, thus contributing to attraction of flower 
visitors. This strategy has also been described for other species of the genus Jacquemontia as: J. nodiflora (KIILL \& Simão-Bianchini, 2011), J. montana (Silva et al., 2010), J. multiflora (Piedade-KiIll \& Ranga, 2000). These characteristics are essentials, especially because many species of Convolvulaceae are creeping plants that occur in open areas with high light incidence, characteristics of anthropogenic environments.

Although quite attractive, $J$. bracteos a flowers had short duration and self-compatibility. This short duration of flower can somehow be related to the self-pollinating reproduction system, which would ensure pollination even in the absence of external agents. These aspects may be important when considering the condition of ruderal plant of this species. The self-compatibility in short duration flowers ensure reproductive success in the pollinator absence (Primack, 1985). Floral longevity may be related to the reproductive system, where plants that self pollinate, need not be exposed to visitors for long periods (AsHMAN et al., 2004).

In spite of the short duration of Convolvulaceae flowers, they were visited by many insects. Bees were the most frequent and common, especially species of Apidae and Halictidae which collected nectar and/or pollen. Others authors studying the Convolvulaceae family also noted the importance of Apidae bees, which usually prevailed in number of species and individuals on flowers (PIEDADEKiIll \& Ranga, 2000; KiIll \& Simão-Bianchini, 2011; PACHeCo Filho et al., 2011; PAZ et al., 2013).

Ancyloscelis apiformis was the most frequent species visiting flowers of $J$. bracteosa to collect resources. The high frequency of legitimate visits may increase the chances of pollen deposition on the stigma of flowers, consequently, increasing the seed production (МоттеN et al., 1981). However, only frequency does not guarantee an efficient pollination, being necessary other adjustments of the visitors with the flowers, such as the morphological and behavioral. Besides visitor frequency and the form that occurs the pollen deposition, also important is when the pollen distribution takes place (RoubIK, 1989). Accordingly, A. apiformis females showed morphology and behavior that favored the contact with stigma and anthers of the flowers. Furthermore, there was fruit set with only three bee visits to flowers, thus confirming the role of this bee species as efficient pollinator of $J$. bracteosa.

The interaction between A. apiformis and flowers of $J$. bracteosa may indicate a floral preference, since this bee species is recorded as frequent visitor in other genera of Convolvulaceae as Ipomoea and Merremia (ALves-DosSAntos, 1999a; Pick \& Schlindwein, 2011).

Male of $A$. apiformis also visited the $J$. bracteosa flowers in their nectar foraging presenting agonistic behavior with other bees, probably in defense of territory. Similar behavior was observed by Alves-Dos-Santos (1999b) with males of several species of Ancyloscelis in plants from different families, including Convolvulaceae. This activity can also influence the pollination efficiency in the flower, since males apparently defended flowers of the other visitor species that might be less efficient. The bees of the genus Ancyloscelis visited three species of Convolvulaceae, in northeastern Brazil: Ipomoea bahiensis, Ipomoea nil, and Merremia aegyptia, where males patrolled the flowers searching for females (PICK \& SchlindweIn, 2011). The territorialism observed in males of some bee species is characterized by these bees in protecting the food source for themselves and especially for their females, ensuring that they have access to quality resources and therefore acting for the reproductive success of bee and plant (WILLMER et al., 1994).

Other bee species also visited flowers of $J$. bracteosa, such as Augochlora spp., T. spinipes, and C. maculifrons, considered common on flowers, being the genus Augochlora the most frequent. The behavior of these bees for collecting pollen was similar to females of $A$. apiformis, thus they were considered potential relevant pollinators. In J. multiflora were also observed species of Augochlora and T. spinipes on flowers, in an area of Caatinga in northeastern Brazil, being the first considered an occasional pollinator and the second the main pollinator (PIEDADE-KIILL \& RANGA, 2000).

The contact with the reproductive parts of the flower was somehow facilitated by the small size of bees, so reaching the end of the narrow corolla tube, favoring pollination, although the flower have been considered large. Because the narrowing of the corolla limited the bee movement during the collection of resources, thus increasing body contact with the flower reproductive parts. The relation between visitor size and floral size and form in Convolvulaceae can also be observed in study with $I$. carnea which had larger flowers, pollinated by medium-sized bees, as $A$. mellifera and Melitoma aff. segmentaria (FABRICIUS, 1804) (PAZ et $a l ., 2013)$. Based on the data from this study and also on the literature (Alves-dos-Santos, 1999a; PicK \& SCHLIndweIn, 2011; PAZ et al., 2013) we may suggest the importance of the relationship between floral visitor size and flower size for efficient pollination of Convolvulaceae.

Despite the flowers of $J$. bracteosa were selfcompatible and had short duration, they presented several important characteristics for attraction and maintenance of floral visitors. Some of these characteristics are: annual flowering, large number of flowers, showy corolla, presence of landing platform that facilitates the access of visitors to resources, presence of abundant pollen, and nectar production. These aspects associated with the condition of ruderal plant of $J$. bracteosa, which occurs in anthropized areas, allows considering this plant as important to the maintenance of native pollinators where resource availability is irregular. Furthermore, flowers of $J$. bracteosa were showy, thereby facilitating the use as ornamental plants in disturbed areas, thus increasing the availability of food resources for pollinators.

Acknowledgements. The authors would like to thank Fernando Cezar V. Zanella (Universidade Federal da Integração Latino-Americana), for identifying the bee species and Efigenia de Melo (Universidade Estadual de Feira de Santana) for identifying specimens of Jacquemontia bracteosa. 


\section{REFERENCES}

Alves-Dos-Santos, I. 1999a. Abelhas e plantas melíferas da Mata Atlântica, restinga e dunas de Litoral norte do Estado do Rio Grande do Sul. Revista Brasileira de Entomologia 43:191-223.

Alves-Dos-Santos, I. 1999b. Aspectos morfológicos e comportamentais dos machos de Ancyloscelis Latreille (Hymenoptera, Apoidea). Revista Brasileira de Zoologia 16(2):37-43.

Ashman, T. L.; Knight, T. M.; Steets, J. A.; Amarasekare, P.; Burd, M.; Campbell, D. R.; Dudash, M.; Johnston, M. O.; Mazer, S. J.; Mitchell, R. J.; Morgan, M. T. \& Wilson, W. 2004. Pollen limitation of plant reproduction: Ecological and evolutionary causes and consequences. Ecology 85:2408-2421.

DAFNI, A. \& MAUÉS, M. M. 1998. A rapid and simple procedure to determine stigma receptivity. Sexual Plant Reproduction 11:177-180.

Dafni, A.; Kevan, P. G. \& Husband, B. C. 2005. Practical pollination biology. Cambridge, Enviroquest. 590p.

Ferreira, P. P. A. \& Miotto, S. T. S. 2009. Flora ilustrada do Rio Grande do Sul: Sinopse das espécies de Ipomoea L. (Convolvulaceae) ocorrentes no Rio Grande do Sul, Brasil. Revista Brasileira de Biociências 7(4):440-453.

Frankie G. W.; Haber W. W.; Opler, P. A. \& Bawa, K. S 1983. Characteristics and organization of the large bee pollination system in the Costa Rican dry forest. In: Jones, C. E. \& Little, R. J. eds. Handbook of experimental pollination biology. New York, Van Nostrand Reinhold, p. 441-448.

Judd, W. S.; Campbell, C. S.; Kellogg, E. A.; Stevens, P. F. \& Donoghue M. J. 2009. Sistemática vegetal: um enfoque filogenético. Porto Alegre, Artmed. 632p.

KiILl L. H. P. \& Ranga, N. T. 2003. Ecologia da polinização de Ipomoea asarifolia (Ders.) Roem. and Schult. (Convolvulaceae) na região semiárida de Pernambuco. Acta Botânica Brasilica 17:355-362.

KiILl, L. H. L. \& Simão-Bianchini, R. 2011. Biologia reprodutiva e polinização de Jacquemontia nodiflora (Desr.) G. Don (Convolvulaceae) em Caatinga na região de Petrolina, PE, Brasil. Hoehnea 38(4):511-520.

Machado, I. C. \& Lopes, A. V. 2004. Floral traits and pollination systems in the Caatinga, a Brazilian tropical dry forest. Annals of Botany 94:365-376.

Maia-Silva, C.; Silva, C. I.; Hrncir, M.; Queiroz, R. T. \& ImPeratrizFONSECA, V. 2012. Guia de plantas visitadas por abelhas na Caatinga. Fortaleza, Fundação Brasil Cidadão. 191p.

Maimoni-Rodella, R. C. S. \& Yanagizawa, Y. 2007. Floral biology and breeding system of three Ipomoea weeds. Planta Daninha 25:35-42.

McDonald, A. 1991. Origin and Diversity of Mexican Convolvulceae. Anales del Instituto de Biología, Serie Botanica 62(1):65-82.

MCMullen, C. K. 2009. Pollination biology of a night-flowering Galápagos endemic Ipomoea habeliana (Convolvulaceae). Botanical Journal of the Linnean Society 160:11-20.

Motten, A. F.; Campbell, D. R.; Alexander, D. E. \& Miller, H. L. 1981. Pollination efectiveness of specialist and generalist visitors to a North Carolina population of Claytonia virginica. Ecology 62:1278-1287.
Moure. J. S.; Urban, D. \& Melo, G. A. R. orgs. 2012. Catalogue of Bees (Hymenoptera, Apoidea) in the Neotropical Region. Available at $<\mathrm{http}$ ://www.moure.cria.org.br/catalogue $>$. Accessed on 03 November 2012.

Pacheco Filho, A. J. S.; Westerkamp, C. \& Freitas, B. M. 2011. Ipomoea bahiensis pollinators: Bees or butterflies? Flora 206:662-667.

Paz, J. R. L.; Gimenes, M. \& Pigozzo, C. M. 2013. Three timing of anthesis in Ipomoea carnea subsp. fistulosa (Convolvulaceae): implications for temporal, behavioral and morphological characteristics of pollinators? Flora 208(2):138-146.

Pick, R. A. \& Schlindwein, C. 2011. Pollen partitioning of three species of Convolvulaceae among oligolectic bees in the Caatinga of Brazil. Plant Systematics and Evolution 293:147-159.

Piedade-Killl, L. H. \& Ranga, N. T. 2000. Biologia floral e sistema de reprodução de Jacquemontia multiflora (Choisy) Hallier f. (Convolvulaceae). Revista Brasileira de Botânica 23(1):37-43.

Primack, R. B. 1985. Longevity of individual flowers. Annual Review of Ecology and Systematics 16:15-37.

RoubiK, D. W. 1989. Ecology and natural history of tropical bees. Cambridge, Cambridge University Press. 514p.

Santana, J. R. F. \& Santos, G. M. M. 1999. Arborização do campus da UEFS: um exemplo a ser seguido ou um grande equívoco? Sitientibus, Série Ciências Biológicas 20:103-107.

SCogin, R.; Young, D. A. \& Jones, C. E. 1977. Anthochlor pigments and pollination biology: II. The ultraviolet patterns of Coreopsis gigantea (Asteraceae). Bulletin of the Torrey Botanical Club 104:155-159.

SEI. 2012. Superintendência de Estudos Econômicos e Sociais da Bahia. Informações Geográficas: Clima e Vegetação. Available at $<$ http:// www.sei.ba.gov.br/>. Accessed on 10 August 2012.

Silva, F. O.; Kevan, S. D.; Rogue, N.; Viana, B. F. \& Kevan, P. G. 2010. Records on floral biology and visitors of Jacquemontia montana (Moric.) Meisn. (Convolvulaceae) in Mucugê, Bahia. Brazilian Journal of Biology 70(3):671-676.

Simão-Bianchini, R. 1999. Jacquemontia revoluta (Convolvulaceae), a new species from Minas Gerais, Brazil. Novon 9:104-106.

Simão-Bianchini, R. \& Pirani, J. R. 2005. Duas novas espécies de Convolvulaceae de Minas Gerais, Brasil. Hoehnea 32(2):295-300.

Thomazini, M. J. \& Thomazini, A. P. B. W. 2002. Diversidade de Abelhas (Hymenoptera: Apoidea) em inflorescências de Piper hispidinervum (C.DC.). Neotropical Entomology 31:27-34.

Timossi, P. C. \& Durigan, J. C. 2006. Convolvulaceae Management in Soybean Sown Directly Under Sugar-cane Straw. Planta Daninha 24(1):91-98.

VIDAL, W. N. \& VidAL, M. R. R. 2000. Botânica à Organografia - Quadros Sinóticos Ilustrados de Fanerógamos. Viçosa, Universidade Federal de Viçosa. 124p.

Willmer, P.; Gilbert, F.; Ghazoul, J.; Zalat, S. \& Semida, F. 1994. A novel form of territoriality: daily paternal investment in an anthophorid bee. Animal Behaviour 48:535-549. 